\title{
Gordonia malaquae sp. nov., isolated from sludge of a wastewater treatment plant
}

\author{
Correspondence \\ A. F. Yassin \\ yassin@mibi03.meb.uni-bonn.de
}

\author{
A. F. Yassin, ${ }^{1}$ Fo-Ting Shen, ${ }^{2}$ H. Hupfer, ${ }^{3}$ A. B. Arun, ${ }^{2}$ Wei-An Lai, ${ }^{2}$ \\ P. D. Rekha ${ }^{2}$ and Chiu Chung Young ${ }^{2}$
${ }^{1}$ Institut für Medizinische Mikrobiologie und Immunologie der Universität Bonn, 53127 Bonn Germany
${ }^{2}$ College of Agriculture and Natural Resources, Department of Soil and Environmental Sciences, National Chung Hsing University, Taichung 402, Taiwan ROC
${ }^{3}$ Kekulé-Institut für Organische Chemie und Biochemie der Universität Bonn, 53121 Bonn, Germany

\begin{abstract}
The taxonomic status of a bacterial isolate from the sludge of a wastewater treatment plant was characterized by using a polyphasic taxonomic approach. Chemotaxonomic investigations revealed the presence of cell-wall chemotype IV, short-chain mycolic acids that co-migrated with those extracted from members of the genus Gordonia, fatty acids $\mathrm{C}_{16: 0}$ and $\mathrm{C}_{18: 0}$ (found by pyrolysis gas chromatography) and a dihydrogenated menaquinone with nine isoprene units [MK-9(H2)] as the predominant menaquinone. The genus assignment was confirmed by $16 \mathrm{~S}$ rRNA gene sequencing. Comparative analysis of the 16S rRNA gene sequence showed that the novel isolate constitutes a hitherto unknown subline within the genus Gordonia, displaying 95.9 to $97.6 \%$ gene sequence similarity to the recognized species of the genus. The novel isolate was distinguished from the type strains of phylogenetically related species by using a set of phenotypic features. The genotypic and phenotypic data show that the new strain merits classification as a novel species of the genus Gordonia, for which the name Gordonia malaquae sp. nov. is proposed. The type strain is IMMIB WWCC- $22^{\top}$ (=DSM $45064^{\top}=$ CCUG $\left.53555^{\top}\right)$.
\end{abstract}

The genus Gordonia belongs to the suborder Corynebacterineae (Stackebrandt et al., 1997). The genus Gordonia has attracted much interest in recent years for a variety of reasons. In contrast to the originally isolated strains of the genus, which were described as opportunistic pathogens in humans (Tsukamura, 1971, 1978, 1982), most members of the genus Gordonia described recently represent environmental isolates that play an important role in bioremediation and the biodegradation of pollutants (Bendinger et al., 1995; Klatte et al., 1996; Kim et al., 2000; Linos et al., 2002; Kageyama et al., 2006; Soddell et al., 2006). At the time of writing, the genus Gordonia includes 22 species with validly published names. The aim of this study was to clarify the taxonomic position of strain IMMIB WWCC $-22^{\mathrm{T}}$ which was isolated from the sludge of a wastewater treatment plant. Based on phylogenetic and phenotypic evidence, it is proposed that this new isolate be classified as a novel species of the genus Gordonia.

Strain IMMIB WWCC- $22^{\mathrm{T}}$ was isolated from the sludge of a wastewater treatment plant located in Taichung Industrial Park, Taichung city, Taiwan. The organism was cultivated

The GenBank/EMBL/DDBJ accession number for the 16S rRNA gene sequence of strain IMMIB WWCC-22 ${ }^{\top}$ is AM406674. on Columbia agar supplemented with $5 \%$ sheep blood agar and brain-heart infusion (BHI) agar to determine its morphological characteristics. Pigment production was determined by growing the strain at $27^{\circ} \mathrm{C}$ for 7 days; observations were made at $24 \mathrm{~h}$ intervals. Air-dried smears were stained by the Gram method in order to determine the Gram stain and cell morphology. The Ziehl-Neelsen method was used to determine acid-fastness. Growth temperatures were determined by incubating the strain at 27,37 and $42{ }^{\circ} \mathrm{C}$. The physiological properties of the novel strain were determined by using tests to determine the hydrolysis of complex substrates as described previously (Gordon, 1966, 1967; Gordon \& Mihm, 1957) as well as tests to determine carbon source utilization according to Yassin et al. (1995). The isomeric form of the diaminopimelic acid was determined by the method of Becker et al. (1964) and whole-cell sugars were determined according to Lechevalier (1968). Lipids were extracted using acid methanolysis and mycolic acids were detected with TLC as described by Minnikin et al. (1980); pyrolysis GC of the mycolate was performed according to Yassin et al. (1993a). Non-hydroxylated fatty acids were purified, identified and quantified by GC as described by Yassin (1988). Phospholipids were extracted, purified and identified as described previously (Yassin et al., 1993b). Menaquinones were extracted and purified according to 
Collins et al. (1977). Mass spectral analyses of the menaquinones were recorded as described recently by Yassin \& Hupfer (2006) in positive ion mode on a Q-TOF 2 mass spectrometer (Micromass) equipped with a nanospray source.

Genomic DNA extraction, PCR-mediated amplification of the 16S rRNA gene and the purification of PCR products were carried out using previously described procedures (Rainey et al., 1996). Purified PCR products were sequenced using a Taq DyeDeoxy Terminator cycle sequencing kit (Applied Biosystems) according to the manufacturer's protocol. A Genetic Analyzer (310 DNA; Applied Biosystems) was used for electrophoresis of the sequence reaction products. The $16 \mathrm{~S}$ rRNA gene sequences of strain IMMIB WWCC $-22^{\mathrm{T}}$, as well as those of the other recognized species of the genus Gordonia retrieved from GenBank, were added to the ARB-database (Ludwig et al., 2004) and aligned using the appropriate tool from the ARB package. The resulting alignment was corrected manually and evolutionary trees were inferred using maximum-parsimony (Fitch, 1971), neighbour-joining (Saitou \& Nei, 1987) and maximumlikelihood (Felsenstein, 1981) methods. An evolutionary distance matrix was calculated using the correction of Jukes \& Cantor (1969). The topologies of the resultant trees were evaluated by bootstrap analyses (Felsenstein, 1985) of the neighbour-joining data based on 1000 resamplings using the ARB package.

To establish the phylogenetic position of strain IMMIB WWCC- $22^{\mathrm{T}}$, its $16 \mathrm{~S}$ rRNA gene sequence was determined in this study [1489 nucleotides; $96.5 \%$ of the Escherichia coli sequence (Brosius et al., 1978)]. A tree depicting the phylogenetic relationship of the novel strain within the genus Gordonia is shown in Fig. 1. The novel strain formed a distinct subline within the genus Gordonia, branching proximal to the base of a subcluster of species, which includes Gordonia hirsuta, Gordonia amarae, Gordonia sihwensis and Gordonia hydrophobica. Bootstrap resampling, however, showed that the association of strain IMMIB WWCC- $22^{\mathrm{T}}$ with this subcluster of species is not statistically significant and, from the tree construction analysis, it is evident that the novel strain does not exhibit a significant affinity with any recognized species. The novel strain shared closest $16 \mathrm{~S}$ rRNA gene sequence similarity with the type strains of $G$. hydrophobica (97.6\%), Gordonia defluvii (97.5\%), Gordonia rubripertincta (97.4\%), Gordonia desulfuricans, (97.3\%), Gordonia namibiensis (97.3\%), Gordonia alkanivorans (97.2\%), Gordonia westifalica (97.2\%), G. sihwensis (97.1\%) and Gordonia amicalis (97.1\%). Lower 16S rRNA gene sequence similarities were found with the type strains of the remaining Gordonia species. DNA-DNA relatedness studies were not carried out between strain IMMIB WWCC- $22^{\mathrm{T}}$ and its phylogenetically closest relatives as it has already been established that representatives of other Gordonia species with similar 16S rRNA gene sequence similarities, for example Gordonia araii and Gordonia effusa and the type strains of G. amarae, G. hydrophobica and G. hirsuta (Kageyama et al., 2006), share DNA-DNA relatedness values well below the $70 \%$ cut-off point recommended for the delineation of bacterial species (Wayne et al., 1987). The novel strain can be distinguished from its phylogenetically closest relatives by using a combination of phenotypic properties (Table 1).

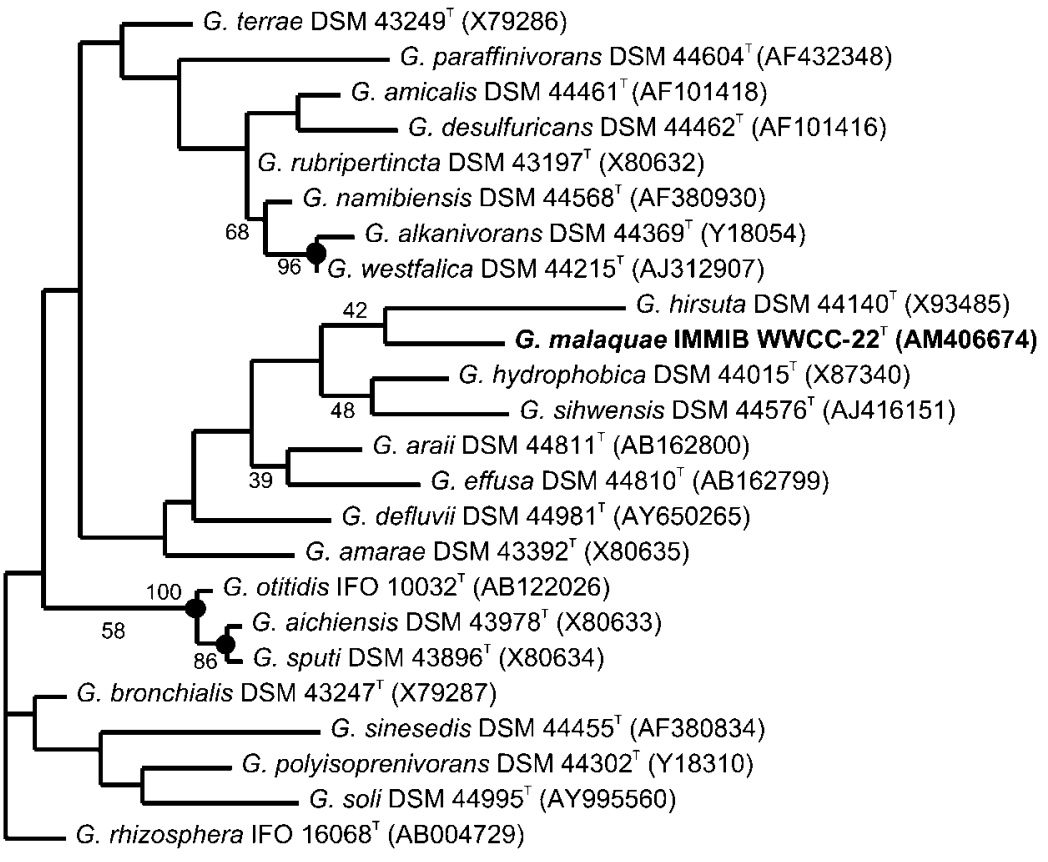

5.0
Fig. 1. Maximum-likelihood tree showing the position of Gordonia malaquae sp. nov. IMMIB WWCC $-22^{\top}$ in the genus Gordonia. The tree was based on comparison of $16 \mathrm{~S}$ rRNA gene sequences that were at least $90 \%$ complete (with regard to the E. coli sequence). Numbers at nodes are levels of bootstrap support (\%) based on analyses of 1000 resampled datasets. Solid circles indicate that the corresponding nodes (groupings) are also recovered in neighbour-joining and maximum-parsimony trees. Bar, 5.0\% sequence divergence. 
Table 1. Differential physiological characteristics of strain IMMIB WWCC- $22^{\top}$ and other members of the genus Gordonia

Strains: 1, Gordonia malaquae sp. nov. IMMIB WWCC-22 ${ }^{\mathrm{T}} ; 2, G$. desulfuricans DSM $44462^{\mathrm{T}} ; 3$, G. hirsuta DSM $44140^{\mathrm{T}}$ (data from Linos et al., 2002); 4, G. hydrophobica DSM 44015 ${ }^{\mathrm{T}}$; 5, G. rubripertincta DSM $43197^{\mathrm{T}}$; 6, G. sihwensis DSM $44576^{\mathrm{T}}$ (Kim et al., 2003). All strains (not determined for strain numbers 3 and 4) were positive for acetate, 2,3-butandiol, citrate, glucose, paraffin and trehalose and for hydrolysis of testosterone and urea. All strains (not determined for strain numbers 3 and 4) were negative for the utilization of adipic acid, adonitol, isoamyl alcohol, L-arabinose, cellobiose, gelatin, lactate, lactose, maltose, melezitose, raffinose, rhamnose and D-xylose and for the hydrolysis of adenine, casein, elastin, aesculin, gelatin, guanine, hypoxanthine, tyrosine and xanthine. +, Positive; -, negative; w, weakly utilized after three weeks incubation; ND, not determined.

\begin{tabular}{|c|c|c|c|c|c|c|}
\hline Characteristic & 1 & 2 & 3 & 4 & 5 & 6 \\
\hline \multicolumn{7}{|c|}{ Utilization as sole sources of carbon and energy: } \\
\hline meso-Erythritol & $\mathrm{W}$ & - & ND & - & - & ND \\
\hline D-Galactose & - & - & + & - & - & + \\
\hline Gluconate & - & + & - & - & + & + \\
\hline$p$-Hydroxybenzoate & - & + & - & - & - & - \\
\hline myo-Inositol & - & - & + & - & - & - \\
\hline Mannitol & $\mathrm{W}$ & - & ND & - & + & ND \\
\hline 1,2-Propandiol & - & - & ND & + & + & ND \\
\hline Sorbitol & - & - & ND & - & + & ND \\
\hline Sucrose & + & + & - & + & + & + \\
\hline \multicolumn{7}{|c|}{ Utilization as sole sources of carbon and nitrogen: } \\
\hline Acetamide & - & + & - & + & - & - \\
\hline L-Alanine & + & + & - & + & + & - \\
\hline Arginine & - & + & ND & - & - & ND \\
\hline Ornithine & - & - & ND & - & + & ND \\
\hline Proline & + & - & - & + & - & + \\
\hline Serine & + & - & - & - & + & + \\
\hline
\end{tabular}

Strain IMMIB WWCC- $22^{\mathrm{T}}$ has morphological properties consistent with its assignment to the genus Gordonia. The organism is aerobic and forms smooth, creamy colonies on Columbia and BHI agars. The cells are rod- and coccoidlike, stain Gram-positive and are non-acid-alcohol-fast. The novel strain grows at temperatures up to $37^{\circ} \mathrm{C}$, but not at $42{ }^{\circ} \mathrm{C}$. The physiological properties of strain IMMIB WWCC- $22^{\mathrm{T}}$ are given in detail in the species description below. The biochemical characteristics determined in this study that distinguish strain IMMIB WWCC- $22^{\mathrm{T}}$ from $G$. desulfuricans DSM 44462 ${ }^{\mathrm{T}}$, G. hydrophobica DSM $44015^{\mathrm{T}}$ and G. rubripertincta DSM $43197^{\mathrm{T}}$ are presented in Table 1.

Chemotaxonomically, strain IMMIB WWCC $-22^{\mathrm{T}}$ possesses chemical markers consistent with its phylogenetic assignment to the genus Gordonia. The cell wall contains mesodiaminopimelic acid as well as arabinose and galactose (i.e. wall chemotype IV sensu Lechevalier \& Lechevalier, 1970). One-dimensional TLC of whole-cell acid methanolysates of the novel strain revealed the presence of two lipid spots on the chromatogram. The lower spot corresponded to mycolic acids, as identified from its $R_{\mathrm{F}}$ value (0.55), and the higher spot corresponded to non-hydroxylated fatty acids. Pyrolysis GC of the purified mycolic acid methyl esters from strain IMMIB WWCC $-22^{\mathrm{T}}$ released fatty acid methyl esters of $\mathrm{C}_{16: 0}\left(29 \%\right.$ of total cleavage products) and $\mathrm{C}_{18: 0}(71.0 \%)$ as pyrolysis cleavage products. GC analyses of the nonhydroxylated fatty acid methyl esters revealed the presence of dodecanoate $(0.9 \%$ of total fatty acids), tetradecanoate $(5.0 \%)$, pentadecanoate $(0.9 \%)$, cis-hexadecenoate $(5.0 \%)$, hexadecanoate $(40.0 \%)$, heptadecanoate $(1.6 \%)$, octadecenoate $(14.4 \%)$, octadecanoate $(18.5 \%)$, tuberculostearic acid (10-methyl octadecanoate, $13.2 \%)$, eicosenoate (1.0\%) and eicosanoate $(0.15 \%)$ as the major cellular fatty acid methyl esters. Polar lipid analysis showed that the novel strain contains phosphatidylethanolamine, phosphatidylinositol, phosphatidylinositol dimannosides, phosphatidylglycerol and diphosphatidylglycerol as the characteristic phospholipids (i.e. phospholipid type PII sensu Lechevalier et al., 1977). Mass spectral analysis of the main component from strain IMMIB WWCC- $22^{\mathrm{T}}$ shows a strong peak at $\mathrm{m} / \mathrm{z} 809.5$ attributable to $[\mathrm{M}+\mathrm{Na}]^{+}$in the high mass region. This corresponds to a dihydrogenated menaquinone with nine isoprene units MK-9(H2). The second band shows a strong peak at $\mathrm{m} / \mathrm{z} 741.58$ attributable to $[\mathrm{M}+\mathrm{Na}]^{+}$in the high mass region. This corresponds to a dihydrogenated menaquinone with eight isoprene units, MK-8(H2).

It is apparent from the genotypic and phenotypic data that strain IMMIB WWCC- $22^{\mathrm{T}}$ represents a novel species of the genus Gordonia, for which the name Gordonia malaquae is proposed.

\section{Description of Gordonia malaquae sp. nov.}

Gordonia malaquae (mal.a'quae. L. adj. malus bad; L. n. aqua water; N.L. gen. n. malaquae of bad water, effluent).

Forms smooth, cream coloured colonies on agar media. Cells are rod- and coccoid-like, Gram-positive and nonacid-alcohol-fast. Grows at temperatures between $22-37^{\circ} \mathrm{C}$, but not at $42^{\circ} \mathrm{C}$. Contains the salient chemotaxonomic characteristic of the genus Gordonia. Mycolic acids cleave on pyrolysis to release fatty acids of $\mathrm{C}_{16: 0}$ and $\mathrm{C}_{18: 0}$ as the major cleavage products. The fatty acid profile consists mainly of straight-chain saturated, unsaturated and 10methyl branched fatty acids. Hydrolyses urea and testosterone, but not adenine, casein, elastin, aesculin, gelatin, guanine, hypoxanthine, tyrosine or xanthine. Assimilates acetate, 2,3-butandiol, citrate, glucose, paraffin, sucrose, trehalose and xylose as carbon sources but not adonitol, adipate, iso-amylalcohol, L-arabinose, cellobiose, mesoerythritol, galactose, gluconate, $m$-hydroxybenzoate, $p$ hydroxybenzoate, myo-inositol, lactate, lactose, maltose, mannitol, melezitose, 1,2-propandiol, raffinose, rhamnose or sorbitol. Utilizes L-alanine, proline and serine as simultaneous carbon and nitrogen sources, but not acetamide, arginine, gelatin or ornithine. 
The type strain, IMMIB WWCC- $22^{\mathrm{T}}\left(=\mathrm{DSM} 45064^{\mathrm{T}}=\right.$ CCUG $53555^{\mathrm{T}}$ ), was isolated from sludge from a wastewater treatment plant, Taiwan.

\section{Acknowledgements}

We thank Professor Dr Hans-Georg Trüper for nomenclatural advice.

\section{References}

Becker, B., Lechevalier, M. P., Gordon, R. E. \& Lechevalier, H. A. (1964). Rapid differentiation between Nocardia and Streptomyces by paper chromatography of whole cell hydrolysates. Appl Microbiol 12, 421-423.

Bendinger, B., Rainey, F. A., Kroppenstedt, R. M., Moormann, M. \& Klatte, S. (1995). Gordona hydrophobica sp. nov., isolated from biofilters for waste gas treatment. Int J Syst Bacteriol 45, 544-548.

Brosius, J., Palmer, M. L., Kennedy, P. J. \& Noller, H. F. (1978). Complete nucleotide sequence of a $16 \mathrm{~S}$ ribosomal RNA gene from Escherichia coli. Proc Natl Acad Sci U S A 75, 4801-4805.

Collins, M. D., Pirouz, T., Goodfellow, M. \& Minnikin, D. E. (1977). Distribution of menaquinones in actinomycetes and corynebacteria. $J$ Gen Microbiol 100, 221-230.

Felsenstein, J. (1981). Evolutionary trees from DNA sequences: a maximum likelihood approach. J Mol Evol 17, 368-376.

Felsenstein, J. (1985). Confidence limits on phylogenies: an approach using bootstrap. Evolution 39, 783-791.

Fitch, W. M. (1971). Toward defining the course of evolution: minimum change for a specific tree topology. Syst Zool 20, 406-416.

Gordon, R. E. (1966). Some criteria for the recognition of Nocardia madurae (Vincent) Blanchard. J Gen Microbiol 45, 355-364.

Gordon, R. E. (1967). The taxonomy of soil bacteria. In The Ecology of Soil Bacteria, pp. 293-321. Edited by T. R. G. Gray \& B. Parkinson. Liverpool: University Press.

Gordon, R. E. \& Mihm, J. M. (1957). A comparative study of some strains received as nocardiae. J Bacteriol 73, 15-27.

Jukes, T. H. \& Cantor, C. R. (1969). Evolution of protein molecules. In Mammalian Protein Metabolism, pp. 21-132. Edited by H. N. Munro. New York: Academic Press.

Kageyama, A., lida, S., Yazawa, K., Kudo, T., Suzuki, S.-i., Koga, T., Saito, H., Inagawa, H., Wada, A. \& other authors (2006). Gordonia araii sp. nov. and Gordonia effusa sp. nov., isolated from patients in Japan. Int J Syst Evol Microbiol 56, 1817-1821.

Kim, S. B., Brown, R., Oldfield, C., Gilbert, S. C., Iliarionov, S. \& Goodfellow, M. (2000). Gordonia amicalis sp. nov., a novel dibenzothiophene-desulphurizing actinomycete. Int $J$ Syst Evol Microbiol 50, 2031-2036.

Kim, K. K., Lee, C. S., Kroppenstedt, R. M., Stackebrandt, E. \& Lee, S. T. (2003). Gordonia sihwensis sp. nov., a novel nitrate-reducing bacterium isolated from a wastewater-treatment bioreactor. Int J Syst Evol Microbiol 53, 1427-1433.

Klatte, S., Kroppenstedt, R. M., Schumann, P., Altendorf, K.-H. \& Rainey, F. A. (1996). Gordona hirsuta sp. nov. Int J Syst Bacteriol 46, 876-880.

Lechevalier, M. P. (1968). Identification of aerobic actinomycetes of clinical importance. J Lab Clin Med 71, 934-944.

Lechevalier, M. P. \& Lechevalier, H. A. (1970). Chemical composition as a criterion in the classification of aerobic actinomycetes. Int $J$ Syst Bacteriol 20, 435-443.
Lechevalier, M. P., de Bièvre, C. \& Lechevalier, H. A. (1977). Chemotaxonomy of aerobic actinomycetes: phospholipid composition. Biochem Syst Ecol 5, 249-260.

Linos, A., Berekaa, M. M., Steinbüchel, A., Kim, K. K., Spröer, C. \& Kroppenstedt, R. M. (2002). Gordonia westfalica sp. nov., a novel rubber-degrading actinomycete. Int J Syst Evol Microbiol 52, 1133 1139.

Ludwig, W., Strunk, O., Westram, R., Richter, L., Meier, H., Yadhukumar, Buchner, A., Lai, T., Steppi, S. \& other authors (2004). ARB: a software environment for sequence data. Nucleic Acids Res 32, 1363-1371.

Minnikin, D. E., Hutchinson, I. G., Caldicott, A. B. \& Goodfellow, M. (1980). Thin-layer chromatography of methanolysates of mycolic acid-containing bacteria. J Chromatogr 188, 221-223.

Rainey, F. A., Ward-Rainey, N., Kroppenstedt, R. M. \& Stackebrandt, E. (1996). The genus Nocardiopsis represents a phylogenetically coherent taxon and a distinct actinomycete lineage: proposal of Nocardiopsaceae fam. nov. Int J Syst Bacteriol 46, 1088-1092.

Saitou, N. \& Nei, M. (1987). The neighbour-joining method: a new method for reconstructing phylogenetic trees. Mol Biol Evol 4, 406-425.

Soddell, J. A., Stainsby, F. M., Eales, K. L., Seviour, R. J. \& Goodfellow, M. (2006). Gordonia defluvii sp. nov., an actinomycete isolated from activated sludge foam. Int J Syst Evol Microbiol 56, 2265-2269.

Stackebrandt, E., Rainey, F. A. \& Ward-Rainey, N. L. (1997). Proposal for a new hierarchic classification system, Actinobacteria classis nov. Int J Syst Bacteriol 47, 479-491.

Tsukamura, M. (1971). Proposal of a new genus, Gordona, for slightly acid-fast organisms occurring in sputa of patients with pulmonary disease and in soil. J Gen Microbiol 68, 15-26.

Tsukamura, M. (1978). Numerical classification of Rhodococcus (formerly Gordona) organisms recently isolated from sputa of patients: description of Rhodococcus sputi Tsukamura sp. nov. Int J Syst Bacteriol 28, 169-181.

Tsukamura, M. (1982). Numerical analysis of the taxonomy of Nocardiae and Rhodococci. Microbiol Immunol 26, 1101-1119.

Wayne, L. G., Brenner, D. J., Colwell, R. R., Grimont, P. A. D., Kandler, O., Krichevsky, M. I., Moore, L. H., Moore, W. E. C., Murray, R. G. E. \& other authors (1987). International Committee on Systematic Bacteriology. Report of the ad hoc committee on reconciliation of approaches to bacterial systematics. Int $J$ Syst Bacteriol 37, 463-464.

Yassin, A. F. (1988). Chemotaxonomische Untersuchungen zur vereinfachten Differenzierung und Identifizierung von aeroben Aktinomyzeten und Mykobakterien. Inaaugural-Dissertation zur erlangung des Doktorgrades der MathematischeNaturwissenschaftlichen Fakultät der Rheinischen FriedrichWilhelms-Universität Bonn (in German).

Yassin, A. F. \& Hupfer, H. (2006). Williamsia deligens sp. nov., isolated from human blood. Int J Syst Evol Microbiol 56, 193-197.

Yassin, A. F., Binder, C. \& Schaal, K. P. (1993a). Identification of mycobacterial isolates by thin-layer and capillary gas-liquid chromatography under diagnostic routine conditions. Zentralbl Bakteriol 278, 34-48.

Yassin, A. F., Haggenei, B., Budzikiewicz, H. \& Schaal, K. P. (1993b). Fatty acid and polar lipid composition of the genus Amycolatopsis: application of fast atom bombardment mass spectrometry to structure analysis of underivatized phospholipids. Int J Syst Bacteriol 43, 414-420.

Yassin, A. F., Rainey, F. A., Brzezinka, H., Burghardt, J., Lee, H. L. \& Schaal, K. P. (1995). Tsukamurella inchonensis sp. nov. Int J Syst Bacteriol 45, 522-527. 